\title{
The Use of Electronic Frog VLE in Assisting Reading Comprehension Activities
}

\author{
Melor Md Yunus*, Nurulhusna Yaacob, Ashairi Suliman \\ Faculty of Education, Universiti Kebangsaan Malaysia, Malaysia
}

Received October 9, 2019; Revised November 22, 2019; Accepted December 26, 2019

Copyright $\bigcirc 2020$ by authors, all rights reserved. Authors agree that this article remains permanently open access under the terms of the Creative Commons Attribution License 4.0 International License

\begin{abstract}
Reading is an essential language skill that equips pupils with knowledge by introducing them a selection of texts and contexts. Pupils' path in reading comprehension involves the ongoing acquisition of the language, the written word and the necessary skills to decode and comprehend the text. In Malaysia, Frog Virtual Learning Environment (Frog VLE) is one of the web-based electronic tools to enhance teaching and learning in an ESL classroom. Thus, the paper aims to identify the Year 5 Primary ESL pupils' perception of electronic Frog VLE in assisting reading comprehension activities. The study employed a survey research design and data were collected from questionnaire distributed to 30 Year 5 Primary ESL pupils and in semi-structured interview with three pupils from a sub urban school. The findings revealed that respondents enjoyed completing the five types of reading comprehension activities using electronic Frog VLE and benefited from it. Nevertheless, the respondents were optimistic about the most challenging task, the high order thinking skills questions. The respondents were also positive about the implementation of reading comprehension activities through electronic Frog VLE web despite the challenges and obstacles perceived. The findings are hoped to provide insights in the integration of virtual learning environment in reading comprehension activities.
\end{abstract}

Keywords Electronic Frog Virtual Learning Environment (VLE), Reading Comprehension, English as a Second Language, Education

\section{Introduction}

Shift 2 in the Preliminary Report Malaysia Education Blueprint (2013-2025) highlights the needs for every child to master both Bahasa Malaysia and English Language.
Therefore, learners should master all four language skills, listening, speaking, reading and writing [1]. Among the four skills, reading is one of the skills that require special attention as it is a productive language process. Hence, it is imperative for students to understand what they have read. According to [2], students' interest in reading might be impeded if they are unable to fathom the text. This is supported by [3] who stated that most children always face difficulties in comprehending the reading text they are reading as they cannot find way in the written text they must read. [4] added that the comprehension difficulties in reading can be explained and viewed in term of a memory deficit. Thus, there is a strong emphasis on identifying the pupils' insights on the reading comprehension activities through Frog VLE. This medium equips an avenue to explore pedagogical implications to benefit students' reading comprehension skill.

According to the schema theory, reading comprehension is an interactive process between the text and the reader's prior background knowledge [5]. [6] highlighted that learning to read well especially for children is a long-term developmental process because at the end of the point, the children would be able to be a competent reader as they could be able to read a variety of material with ease and interest, can read for varying purposes and most importantly can read with comprehension even when the material is neither easy to understand nor intrinsically interesting. Pupils are no more passive readers but active readers throughout the reading comprehension process as they gained the cognitive strengths and helpful patterns of interaction with the reading texts [7]. This is supported by [8] who stated that teachers who strengthen the instruction strategies in reading activities will give positive impact on pupils' improvement in reading comprehension. The instruction strategies suggested by the author include the reading comprehension skills such as skimming, scanning, extensive and intensive reading [8]. This is supported by [9] who believed the good impacts on pupils' learning if 
the teachers consider the different styles of learning and pupils' multiple of intelligences in learning.

[10] discussed that the potential of modern technology, ICTs, online social networks or web-based learning have captured the attention of not only the pupils but the educators. Virtual learning environment, on the other hand is a digital-based learning environment that provide a friendly navigation, backgrounds, sounds, and colours as to attain learner's attention while learning [11], [38]. It is seen as the alternative to motivate students in reading comprehension in ESL classroom [12]

The focus of this study was limited to the reading comprehension activities through Frog VLE (Virtual Learning Environment) only. Studies that deal with other virtual learning environment such as Kahoot, Quizlet, Socrative, Google Classroom, Edmodo, Mentimeter and others. Frog VLE is currently the main learning website which the Malaysian government has adopted for all its 10,000 government aided schools nationwide. In addition, the features of Frog VLE allows for the pupils to participate in reading comprehension activities and also online questionnaire session where their progress in learning and responses to the questionnaire would be automatically control by the teachers. The immediate feedback on the reading comprehension test and responses from questionnaire will be automatically recorded in the researcher's account. Therefore, to facilitate the investigation regarding the respondents' perception of reading comprehension activities through Frog VLE, these questions serve as the guidelines:

1) What are pupils' perceptions on reading comprehension activities through Frog VLE in an ESL classroom?

2) What are the challenges in integrating Frog VLE in the reading comprehension activities?

\section{Literature Review}

\subsection{Reading Skill and Reading Comprehension Activities}

Reading is the important skill for ESL learners and also the most important skill to master out of the four skills in a second language [13]. In addition, [14] stated that reading is the window to all knowledge. Through a successful reading process, it could measure the success of the teaching in term of the pedagogical practices by the teacher and most importantly, the students' achievement [15]. [2] stated that in reading, students need to activate their pre-requisite knowledge to aid their understanding. This is supported by [16] who highlighted that the students will be able to summarise in their own words once their background knowledge are activated.

However, in the context of ESL classroom, [17] stated that the skills in reading comprehension among majority of the ESL students fall below expected proficiency level. This problem is seen as an urge for teachers to train and motivate students to be active in reading lesson and able to solve problems in learning in line with the education aspiration in $21^{\text {st }}$ century learning. Moreover, [18] emphasized the importance of students' motivation in learning. They reported at the end of the study that the interactive and interesting instructional approaches in reading encouraged the students to be motivated to read more and will not easily give up if they face challenges in understanding. Therefore, these researchers illustrated the urgency and need for strong reading skills and interesting instructional approaches among the ESL students need to be increased and improved.

\subsection{Frog Virtual Learning Environment}

[19] described Frog Virtual learning environment (VLE) as a cloud-based learning environment that emulates the traditional face-to-face teaching and learning. In the early days, teaching and learning were more formal and being conducted in the classroom, but due to the rapid growth in technology today, kids' way of learning has changed [20]. Virtual learning environment is seen as the alternative to motivate students in reading comprehension in ESL classroom [12]. For example, the tools used in learning play vital role in enhancing students' participation and motivating them to improve in reading activity [21]. The example of activities in web-based learning could be varies depend of teachers' creativity such as displaying the reading text on screen, online quizzes, blogs, video conferencing and many more [22]. To support the web-based learning tools, [22] stated that the virtual learning environment develop cognitive skills such as logical thinking and interest in learning.

Another feature of virtual learning environment is that students can find and collect first-hand information by themselves during the online activity such as searching the meaning of the words they do not understand [12]. By doing so, teachers could encourage students to be involved in self-paced learning as it could train them to be independent learner. However, there are some basic computer skills and access that should be mastered by teacher such as internet connection as it measures a successful online learning experience and students also require web-controlled skills throughout the learning process [23].

Using virtual learning environment has proven its advantageous in the aspect of students' participation, motivation and also improvement in learning. However, virtual learning environment has its own limitation as it requires greater discipline from the students [24]. Students tend to open others websites or do not complete the assessment given properly as they just guess the answers [25]. This situation portrays that the learning process through web-based not successful. Therefore, teacher 
plays a vital role in classroom instructions such as implementing rules and encouraging good attitudes among students during learning interaction [26]. Moreover, classroom observation is also important in ensuring the students fully engaged and benefit in the learning [25].

\subsection{Reading Comprehension Activities and Frog Virtual Learning Environment}

[27] stated that the virtual learning environment could contribute to the quality of learning experience for pupils especially for ESL learners. This is supported by [28] who stated that the virtual learning environment could enhance their attention towards and understanding of the materials which could lead to subsequent improvement in physical activity behavior. This could be related to the meaningful reading activities that had been carried out through Frog VLE. As stated by [29], the use of ICT such as Frog VLE in teaching and learning came on board because of the need to create new aspects of education that suits the twenty-first century learning. It is evidenced by [30] who stated that the user friendly environment of VLE is suitable to provide users with any sort of instructional facility that educators may need in order to make it easier to teach and to learn such as graphics, videos, animations, sounds, and hyperlinks. Therefore, the virtual learning environment valued efficiency, it extends the speed of communication in the world and it helps teachers and students to keep up to date.

The findings of the following researches resonate with previous research in which [31] disclosed students' Frog VLE usage patterns. The findings of the research found out that the learning contents uploaded in Frog VLE were meaningful and attracted them to focus on learning compared to those to be shared and assigned in the classroom. However, the communication between teachers and pupils is one of the problems raised in this study as some of the pupils stated that there was no communication between pupils and teacher through Frog VLE. Therefore, it indicated that the chances to discuss, asking questions and solving problems were not fully maximized if the pupils engaged in the virtual learning environment. However, it is argued by [32] who stated that the virtual learning environment allowed the pupils to share information, collaborate online, and increase their ability to respond and get feedback from their teachers. They also could interact effectively in the classroom discussion with teachers. Thus, the role of both teachers and pupils are important in determining the successful of the teaching and learning process.

\subsection{Challenges of Integrating Reading Comprehension Activities through Frog VLE}

Despite the advantages and recommendation of integrating Frog VLE, there are some prominent challenges to be considered. [29] stated that technical and encouraging support in using ICT either through school management or the top management at the ministry is one of the challenges. Therefore, without the proper technical and encouraging support in ICT, it would be a negative impact on the implementation of it in learning. Moreover, [29] also highlighted the issues of time and practice. The study mentioned the time consuming issue to first digest the technology, help the pupils to use it in learning, and lack of enough training in handling ICT were among the issues discussed by the researchers.

In addition, another study done by [33] stated that teacher's belief to whether Frog VLE can improve the pupils' performance also measure the degree of pupils' performance teaching and learning of English. The model of accepting technology is furthered discussed by [34] who stated that if the teachers possess positive views on Frog VLE, the intention of using technology will be high and thus give positive impact on the pupils' learning. The result of the study is supported by another [35] stated that some teachers who did not realize the benefits of ICT, lack of technology facilities in schools, lack of class management control, low proficiency in English and limited access to internet also the challenges that cause such belief by teachers. Therefore, the following findings on the challenges guided and give positive insights to carry out this research and thus help the researchers in analysing the findings of the research.

\section{Methodology}

\subsection{Research Design}

This mixed method survey study explores the Year 5 ESL pupils' insights on the reading comprehension activities through Frog VLE. It would be beneficial in identifying fundamental issues that are of concern to the pupils using Frog VLE for reading comprehension activities. The study analysed the survey questionnaire and interview.

\subsection{Respondents}

The respondents in this study involved 30 Year 5 ESL pupils consisting of $15(50 \%)$ boys and $15(50 \%)$ girls from a sub urban school in Hulu Langat, Selangor. The respondents were identified using purposive sampling and the total number of respondents was determined using [36] statistical formula. These group of pupils were chosen because they were the individuals who were directly involved in the reading comprehension activities conducted using Frog VLE before. Therefore, finding out their views on the implementation of reading comprehension activities is very much needed. Their feedbacks are useful for teachers to evaluate the success of failure of the use of virtual learning environment for 
reading comprehension activities.

\subsection{Instruments and Procedure}

The primary instruments of this study were survey questionnaire and semi-structured interview. The reading comprehension test is also used as to support the findings for the primary instruments of the study. First, the respondents were being accessed individually through reading comprehension test in Frog VLE. They were required to answer the reading comprehension activities that comprised five types of activities which were matching questions, fill in the blanks questions, multiple choice questions, WH questions and High Order Thinking Skills (HOTS) questions. The reading comprehension test was conducted for triangulation purposes because the study put forward has to be examined and studied from various different points of views and this included mixing several different methods of collection.

Then, the questionnaire was answered by respondents through Goggle form in their Frog VLE. Part one of the questionnaire solicited the pupils' demographic profile while part two on reading comprehension activities, part three on reading comprehension activities through Frog VLE web and part four on the challenges of using Frog VLE in learning. The four parts of the questionnaire were labelled Section A, Section B, Section C and Section D. Section A comprised of 5 questions. The demographic information collected were gender, primary language, language proficiency, purpose of using Frog VLE and frequency of time they use Frog VLE. Section B comprised of 9 questions with a 5-Level Likert Scale from 'Strongly Disagree' to 'Strongly Agree'. Section C comprised of 10 questions and Section D comprised of 7 questions.

Next, the semi-structured interview with three broad topics was conducted. The semi-structured interview followed inverted funnels protocols which began with closed questions and gradually build to more open-ended questions. They were two questions on participants' opinions about reading comprehension activities, two questions on reading comprehension activities and two questions on Frog VLE in learning. All the questions were constructed by the researchers based on the objectives of the study and relevant to the theoretical framework. The interview questions were then validated by a context expert from UKM who has many years of experience in English language teaching and actively involved in doing research.

\subsection{Data Analysis}

Frequency and percentage were employed to analyse the data. As for the data and responses from the interview, the respondents' views were categorized and analysed according to themes. The qualitative data further consolidated the quantitative data. For the systematic analysis of the qualitative data analysis and presentation, each respondent was coded R001, R011 and R021. While the data analysis of the supporting instruments which was on the reading comprehension test was also analysed quantitatively using percentage.

\section{Findings}

\subsection{Demographic Profile}

There are 15 boys and 15 girls participated in this study. All the respondents are in the age of 11 years old. Based on the demographic data, 29 respondents $(96.7 \%)$ stated that Malay language is their primary language while 1 respondent $(3.3 \%)$ stated other than Malay language and English language as the primary language. In term of the rate of English proficiency, 22 respondents (73.3\%) which showed majority of the respondents rated average, 6 respondents $(20 \%)$ rated their proficiency as weak, while 1 respondent $(3.3 \%)$ rated good and another 1 respondent $(3.3 \%)$ rated excellent for the English proficiency.

\subsection{Usage of Frog VLE}

28 respondents (93.3\%) stated that they used Frog VLE for learning and game purposes and only 2 respondents (6.7\%) stated that they used Frog VLE for game play purpose only. In terms of the duration the respondents spend learning via Frog VLE, 4 respondents (13.3\%) spent more than 4 hours learning via Frog VLE in a week while half of the respondents which are 15 respondents (50\%) spent 3-4 hours in Frog VLE web. 6 respondents (20\%) spent about 1-2 hours and 5 pupils (16.7\%) spent less than 1 hour respectively. The two items on the usage of Frog VLE and the time the respondents spend learning via Frog VLE in a week has confirmed the respondents are fully maximized the usage of Frog VLE. The data indicates that the respondents are familiar with the use of Frog VLE. When the respondents' experience is taken into account, the data may be valid as the it is based on their past experience of using Frog VLE. 


\subsection{Pupils' Perception of Reading Comprehension Skill}

Table 1. Pupils' Perception on Reading Comprehension Skill

\begin{tabular}{|c|c|c|}
\hline & & Mean \\
\hline \multirow[t]{2}{*}{ B7. } & $\begin{array}{l}\text { I apply reading skills such as scanning, skimming } \\
\text { and extensive }\end{array}$ & 3.73 \\
\hline & $\begin{array}{l}\text { reading while completing reading comprehension } \\
\text { activities }\end{array}$ & \\
\hline \multirow[t]{2}{*}{ C5. } & $\begin{array}{l}\text { I try to guess the main ideas of the text on the basis } \\
\text { of pictures, }\end{array}$ & 4.00 \\
\hline & charts or figures & \\
\hline \multirow[t]{2}{*}{ C6. } & $\begin{array}{l}\text { I grasp the gist of the reading material through } \\
\text { quickly reading the }\end{array}$ & 3.93 \\
\hline & first and the last paragraphs & \\
\hline C7. & $\begin{array}{l}\text { I predict the main idea of the whole passage from } \\
\text { its title or subtitles }\end{array}$ & 4.20 \\
\hline
\end{tabular}

Table 1 discussed the pupils' perceptions on reading comprehension skills applied throughout the reading activities. From the table above, item $\mathrm{C} 7$ shows the highest mean score $(\mathrm{M}=4.20)$ with 24 respondents $(80 \%)$ agreed that they predicted the main idea of the whole passage from its title or subtitles. Next, guessing the main ideas of the text on the basis of pictures, charts or figures portrays the second highest of mean score $(\mathrm{M}=4.00)$ on the C5 item with 22 respondents $(76.7 \%)$ generally agree and strongly agree with the statement. From the findings on these two items, it shows that the learners are attracted to the colourful images, figures and bigger font words. This could be supported by [37] that the ESL children are attracted to colourful images and spend a longer time looking at the pictures before they approach and read the reading text given. This situation could be related to the finding on the following items.

To support the above findings, the pupils' responses on B7 and C6 items indicated that mean score of pupils who applied reading skills such as scanning, skimming and extensive reading while completing reading comprehension activities are slightly lower $(\mathrm{M}=3.73)$ with 5 pupils $(16.7 \%)$ strongly agree and 15 pupils $(50 \%)$ agree that they applied these reading skills. Nevertheless, these reading skills are important for them as to complete and score the reading comprehension activities. In addition, the item on $\mathrm{C} 6$ indicated that only 12 pupils $(40 \%)$ with the mean score $(M=3.93)$ grasp the gist of the reading material by quickly reading the first and last paragraphs. Thus, the findings for this section can be concluded that the attractive title and pictures attracted them first then the reading text. The findings are important for the researchers in understanding their nature of ESL learners in the second language learning.

Table 2. Pupils' Perception on Reading Comprehension Skill

\begin{tabular}{|l|l|c|}
\hline & & Mean \\
\hline \multirow{2}{*}{ B3. } & \begin{tabular}{l} 
I could answer 'Matching Questions', 'Fill in the \\
blanks Questions' and ' Multiple Choice \\
\cline { 3 - 3 } \\
Questions' easily and confidently.
\end{tabular} & 4.40 \\
\hline B5. & $\begin{array}{l}\text { I like reading activities that have minimal writing } \\
\text { because the choices of answers are there. }\end{array}$ & 4.53 \\
\cline { 3 - 4 } & &
\end{tabular}

As shown in Table 2, the pupils' responses of the choices of activities in item B3 indicated that majority of the pupils $(96.7 \%)$ with the mean score $(M=4.40)$ preferred matching activities, fill in the blanks activities and multiple choice questions activities in reading comprehension activities. The item in B3 supported the responses in $\mathrm{B} 5$ with the mean score $(\mathrm{M}=4.53)$ as the following activities involve minimal writing and the choices of answers are there. It is now shown that the types of activities in reading comprehension affect the pupils' performance in reading comprehension activities. In addition, from the responses, it is shown that most of the pupils did not encounter problems with these types of reading comprehension activities. In addition to that, several interviewees responded to the interview question 'Among five types of reading comprehension activities, which activities you like the most?' mentioned that they preferred matching; fill in the blanks and multiple choice questions. The interviewees' responses why they preferred the following activities include:

1) 'Could get answer directly from the text' (R001)

2) 'The exercises are easy to read and answer' (R011)

3) 'The questions are simple and easy to score' (R021)

Table 3. Pupils' Perception on Reading Comprehension Skill

\begin{tabular}{|l|l|c|}
\hline & & Mean \\
\hline B4. & $\begin{array}{l}\text { 'WH Questions' and 'HOTS Questions' are very } \\
\text { challenging. }\end{array}$ & 4.37 \\
\hline B6. & $\begin{array}{l}\text { 'HOTS Activities' are challenging because I have } \\
\text { to write my own answers and give reasons. }\end{array}$ & 3.90 \\
\hline
\end{tabular}

To support the findings in items B3 and B5 on the most preferable activities, the researchers acknowledged the pupils' responses from the items B4 and B6. As shown in Table 3, the items in B4 shown that pupils generally agree that 'WH questions' and 'HOTS questions' are the very challenging with the mean score shown $(M=4.37)$. Moreover, 20 respondents $(67 \%)$ with the mean score $(\mathrm{M}=3.90)$ stated that 'HOTS activities' are challenging because they have to write their own answers and give reasons in answering reading comprehension activities.

Table 4. Pupils' Perception on Reading Comprehension Skill

\begin{tabular}{|c|l|c|}
\hline & \multicolumn{3}{|c|}{} & Mean \\
\hline B8. & $\begin{array}{l}\text { My marks are improving in reading } \\
\text { comprehension activities. }\end{array}$ & 4.06 \\
\hline B9. & $\begin{array}{l}\text { I feel enjoyed and relaxed during reading } \\
\text { comprehension activities. }\end{array}$ & 3.80 \\
\hline
\end{tabular}

From the findings on respondents' reading comprehension skills, the pupils benefited from the reading comprehension activities done during class. Despite all the challenges they faced in answering the challenging tasks such as 'HOTS questions' and 'WH questions', 26 respondents $(86.7 \%)$ with the mean score $(\mathrm{M}=4.06)$ agree and strongly agree that their marks are improving in reading comprehension activities. Besides, more than half of the respondents, $(73.3 \%)$ with the mean 
score $(\mathrm{M}=3.80)$ felt enjoyed and relaxed during comprehension activities.

The findings from the above tables show the mean score of positive and very positive responses from the respondents on the reading comprehension activities conducted before. This shows the importance of teacher as the facilitator, while the pupils as the active learners throughout the reading comprehension process. As mentioned by [2], to ensure the successful reading comprehension process, both teacher and pupils should be responsible and actively involve during reading lesson as teachers responsible to guide the pupils to understand the reading text by activating their background knowledge, while the pupils responsible in motivating themselves to learn, understand, comprehend the text and make conclusion before they answer the questions. However, [38] stated that other than teacher and pupils' role during reading class, basic reading skills involves the process of skimming, scanning, extensive and intensive reading support the enhancement of reading skills, which ultimately leads to an improvement in language proficiency. By doing so, it would help the pupils to use and apply the skills during reading lesson or in answering reading comprehension activities.

\subsection{Pupils' Perception of Reading Comprehension Activities through Frog VLE}

This subsection discussed the pupils' perceptions of reading comprehension activities through Frog VLE. The findings are grouped into three categories which are on their motivation, perceptions on Frog VLE and reading comprehension skills through Frog VLE.

Table 5. Pupils' Perceptions on Reading Comprehension Activities through Frog VLE

\begin{tabular}{|l|l|c|}
\hline & \multicolumn{1}{|c|}{} & Mean \\
\hline C2. & $\begin{array}{l}\text { I feel motivated to do reading activities using } \\
\text { Frog VLE because 1 could use computer for } \\
\text { reading }\end{array}$ & 4.37 \\
\hline C4. & $\begin{array}{l}\text { I try my best to answer all reading activities } \\
\text { through Frog VLE }\end{array}$ & 4.27 \\
\hline
\end{tabular}

Table 5 shows the pupils' responses on their motivation using Frog VLE. As stated in the above table, the pupils felt motivated to do reading activities using Frog VLE because they could use computer. The finding of this item indicated significant finding to the research as 28 pupils $(93.3 \%)$ with the mean score $(\mathrm{M}=4.37)$ generally agree and strongly agree with the item asked. Moreover, the pupils also highly motivated because (93.4\%) of the respondents with mean score $(\mathrm{M}=4.27)$ agreed that they have tried their best to answer all reading activities through Frog VLE. In addition, the findings from the interview for the question of 'Do you like reading comprehension activities conducted through Frog VLE?', the researchers found out that the three respondents stated they like the activities to be conducted through Frog VLE. Some other responses given include:

1) 'Could open Frog VLE account' (R001)

2) 'Could use computer to type my answers for the given questions' (R011)

3) 'Get rewards such as open game play if able to answer the questions correctly' (R021)

From the above findings, it shows that Frog VLE could enhance pupils' attention as they could experience the interesting way of reading lesson and activities, hence it will improve their understanding of the reading materials [28]. In addition, it also one of the alternatives used to motivate pupils in reading comprehension in ESL classroom [12].

Table 6. Pupils' Perceptions on Reading Comprehension Activities through Frog VLE

\begin{tabular}{|c|l|c|}
\hline & & Mean \\
\hline C3. & $\begin{array}{l}\text { I prefer reading activities through Frog VLE } \\
\text { because the interactive and instant feedback of } \\
\text { answers. }\end{array}$ & 4.47 \\
\hline C8. & $\begin{array}{l}\text { I am more engaged in reading comprehension } \\
\text { activities through Frog VLE. }\end{array}$ & 4.20 \\
\hline
\end{tabular}

Other than that, the responses from the questionnaire also indicated that $(90 \%)$ with the mean score $(\mathrm{M}=4.47)$ preferred reading activities through Frog VLE because of the interactive and instant feedbacks of answers. Moreover, 25 pupils $(83.3 \%)$ with the mean score $(\mathrm{M}=4.20)$ stated agreed that they are more engaged in reading comprehension activities through Frog VLE. Both items portrayed that all pupils benefited from the interactive and instant feedbacks offered in Frog VLE. This could be supported by the finding from interview on the question 'Did you improve a lot in reading comprehension activities through Frog VLE? Why', (R011) stated that he improved a lot as he could retry to answer the questions he answered wrongly right after he checked the answers. The result of the findings indicated that the use of Frog VLE is effective for both teachers and pupils as the pupils could get immediate feedback and teachers could save time to check pupils' tasks and works. Moreover, the item on pupils' engagement (C8) in the questionnaire also important for the finding because the pupils will try their best and do not easily gives up although they made mistakes in answering the questions.

Based on the above findings, the user-friendly learning environment such as instant feedbacks and interactive web affect the pupils' performance on the reading comprehension activities and also give them positive insights on how the use of ICT gives impact not only on their motivation however, their engagement in learning and performance [30]. 


\subsection{Challenges of Integrating Frog VLE in the Teaching and Learning of Reading Comprehension Activities}

Table 7. Challenges in Integrating Frog VLE

\begin{tabular}{|l|c|}
\hline & Mean \\
\hline $\begin{array}{l}\text { D3. The poor and no internet connection will distract } \\
\text { me to complete the reading activities successfully. }\end{array}$ & 4.20 \\
\hline $\begin{array}{l}\text { D4. I always take a long time to log in to Frog VLE } \\
\text { account as I could not remember my id and password. }\end{array}$ & 3.13 \\
\hline $\begin{array}{l}\text { D6. I could not finish reading comprehension activities } \\
\text { on time like others friends if my computer is hanging. }\end{array}$ & 4.33 \\
\hline
\end{tabular}

The pupils' perception on the challenges of integrating Frog VLE in the teaching and learning of reading comprehension activities are crucial in answering the second research question. Researchers have constructed items D3, D4 and D5 in Section D as the prediction of the challenges that respondents might face when they used Frog VLE for reading comprehension activities. The first item was on the internet connection as Frog VLE requires strong internet connection for pupils to enjoy using it. Based on D3 item, 27 respondents (90\%) with mean score $(\mathrm{M}=4.20)$ which indicated a very high response from the pupils stated that the poor and no internet connection is one of the challenges that distract them in completing the reading comprehension activities successfully. Secondly, only 13 respondents $(43.3 \%)$ with the mean score $(\mathrm{M}=3.13)$ generally agree and strongly agree that they were taking a long time to log in to Frog VLE as they could not remember their id and password. From the responses, it indicated that only the minority of the respondents face this challenge when they wanted to log in to Frog VLE web. Therefore, it is no longer a challenge predicted by the researcher that most of the pupils faced as all pupils were frequently open the Frog VLE web based on the demographic data. Lastly, the problems on the computer such as the computers that keep hanging shows the highest mean score among all the challenges discussed $(\mathrm{M}=4.33)$, with 28 respondents $(93.3 \%)$ agree and strongly agree that this problem will affect their progress in reading comprehension activities as they could not finish the task on time.

To support the findings in questionnaire, the interview inquires respondents on the main challenge of integrating Frog VLE for reading comprehension activities. It was revealed that the main challenge for pupils in integrating Frog VLE was to get connected and stay connected. The challenge identified in this section is crucial to make sure that not all pupils may finish the reading comprehension activities on time as different pupils would have different pace. Besides, some respondents added the following responses to the challenges of using Frog VLE for reading comprehension activities:

1) 'I always forgot my password when I want to log in' (R001)
2) 'Internet connection is the main challenge. We will be so frustrated if there is no internet connection as we could not open the Frog VLE web.' (R011)

3) 'Sometimes, the computer I am using is hanging. I stucked at the certain questions and could not finish answer all questions. It is because due to the poor internet connection'. (R021)

The above findings indicated that the technical problems on the internet connection and computer distracts the reading teaching and learning. This is supported by [29] who highlighted the issue of technical support in using ICT in schools. Moreover, the facilities in school also important in ensuring the pupils enjoy the reading activities effectively. This is supported by [35] who stated that technology facilities in school is one of the challenges that could impact on it. The findings of the pupils' perception on reading comprehensions skills, reading comprehension activities via Frog VLE and also perceptions on the challenges are important for the researchers as to understand the effectiveness of the technique implemented to the pupils before. It also helped the researchers and others readers to understand this survey study in depth.

\section{Discussion}

The purpose of this study was to examine the pupils' perception on reading comprehension activities through Frog VLE in an ESL classroom. In term of pupils' perception, most of the pupils gave positive perceptions on the reading comprehension activities through Frog VLE. It indicated that the pupils prefer virtual learning environment as it offered them the interactive, enjoyable and fun learning that lead to the quality of learning environment [27]. In addition, the pupils were able to state that they applied certain reading comprehension skill such as guessing the main ideas through pictures, reading the first and last paragraph and applied the reading comprehension skill such as skimming, scanning, and many more. The pupils have developed the reading skills through the present of interactive web learning. This could be supported by [2] that highlighted the pupils would be able to comprehend the text well if they have grasp and master the skills in reading as well as activating their background knowledge. The skill in comprehending the text is important as they would be able to apply different skill to different types of text.

Moreover, the researchers able to identify the pupils' perception on the preferable and challenging reading comprehension activities which were the high order thinking skills (HOTS) questions and WH questions. This problem happened to the ESL learners as they could not grasp the most important elements of the text and also connections between the different parts of the text [3]. Moreover, the pupils were not able to understand the questions asked and as the result they were not able to 
search out the information they are looking for. This problem could be solved by integrating the virtual learning environment as to motivate them to stay focus and try their best to answer the challenging tasks given. It is supported by [32] that VLE allowed pupils to interact effectively with the tasks, classroom discussion and teachers as it offers pleasurable environment of learning rather than working in the face-to-face traditional classroom learning. In addition, the researchers also know the pupils' perception on the preferable reading comprehension activities such as matching questions; fill in the blanks and multiple choice questions. Through the findings, it will also provide insights to teachers to know types reading activities that the pupils could perform and also the activities that the pupils struggled with. Through this way, it will guide teachers to design pedagogical approaches that suit the pupils' level and also the pupils will benefit from the meaningful lesson afterwards. The findings of the study have answered the first research question.

Another finding of this study was on the challenges in integrating Frog VLE in the teaching and learning of reading comprehension activities. From the findings of the study, it could be stated that the technical problem was the main challenges faced by teachers and pupils in integrating Frog VLE in reading activities. The findings on the technical problems from the questionnaire could be supported with the data gained from the interview session. Based on the data from the questionnaire and interview session, the poor and no internet connection and technical problems on the computer were identified as the challenges of the study. [29] stated that without proper support on the technical problems such as internet connection and also technical support on the computers, it would affect the teaching and learning process. From the findings, it is found out that the technical problems somehow cause problems to both teachers and pupils and also the teaching and learning process itself as the pupils keep asking teachers to solve the technical problems throughout the learning process. As the result, it will give negative impact on the class management control [35].

According to another study conducted by [39] stated that teachers need to understand the reality of implementing the technologies in the classroom. The researchers highlighted that teachers need to prepare and face any challenges that might happen such as no internet connection or no electricity during the lesson. Therefore, teachers should be competent in designing reading comprehension activities for ESL pupils. If teachers could not use the virtual learning environment due to technical problems, teachers could be creative such as promoting classroom discussion or cooperative learning during the lesson. Through this way, it would help the pupils to keep in track with the learning and also avoid them from being demotivated with the technical problems. This could be related to a study conducted by [34] that highlighted the element of teacher's belief that could give positive impact on the pupils' performance in the classroom. The result of this study is supported by [33] that the degree of pupils' performance in learning is affected of teacher's belief towards the pupils in the classroom. Thus, teachers should be positive in and do not stressed over with the technical problems during the lesson. In short, teachers play important role in solving the challenges of integrating the reading comprehension activities through Frog VLE in the aspect of designed activities, their belief, technical management and knowledge and also classroom control. The findings of the study have answered the second research question.

\section{Conclusions}

The present study contributed to reveal the pupils' perception on reading comprehension activities through Frog VLE and also their perceptions of the challenges in implementing the reading comprehension activities through Frog VLE. The results of this study illustrate the pupils' good perception with the reading comprehension activities conducted through Frog VLE. Moreover, the results of the study also give positive insights to teachers to understand and solve the problems and challenges faced by the pupils in integrating the virtual learning environment in their learning. Therefore, the results of the study indicated that Frog Virtual Learning Environment (VLE) will be a more significant growth area in the of reading comprehension activities for ESL learners. It needs more research and development to be conducted to other primary school from the urban areas. Through this way, it can be ascertained if the findings of the study are applicable to different contexts of learning. Moreover, the suggested study could be conducted with other type of skill such as listening, writing, and speaking skills these skills are the challenging skills in English language among the ESL pupils.

\section{REFERENCES}

[1] Yunus, M. M., Nordin, N., Salehi, H., Sun, C. H., \& Embi, M. A. (2013). Pros and Cons of Using ICT in Teaching ESL Reading and Writing. International Education Studies, 6(7): 119-130.

[2] Chen, L. L., Yunus, M. M., \& Maarof, N. (2017). Factors Affecting ESL Reading Comprehension of Malaysian Secondary School Students. In International Conference on Education (ICE2) 2018: Education and Innovation in Science in the Digital Era. pp. 542-547.

[3] Cornoldi, C., \& Oakhill, J. V. (Eds.). (2013). Reading comprehension difficulties: Processes and intervention. Routledge.

[4] Stothard, S. E., \& Hulme, C. (1992). Reading comprehension difficulties in children. Reading and Writing, 4(3): 245-256. 
[5] Adams, M.J. \& Collins, A.M. (1979). "A schema-theoretic view of reading" in Fredolle, R.O. (ed.) Discourse Processing.' Multidisciplinary Perspectives. Norwood N. J. Ablex.

[6] Snow, C. (2002). Reading for understanding: Toward an $\mathrm{R} \& \mathrm{D}$ program in reading comprehension. Rand Corporation.

[7] Troseth, G. L., Mancilla-Martinez, J., \& Flores, I. (2018). Bilingual Children: Active Language Learners as Language Brokers. In Active Learning from Infancy to Childhood. Springer, Cham. pp. 233-259.

[8] Oczkus, L. D. (2018). Reciprocal teaching at work: Powerful strategies and lessons for improving reading comprehension. ASCD.

[9] Hopper, B., \& Hurry, P. (2000). Learning the MI way: The effects on students' learning of using the theory of multiple intelligences. Pastoral Care in Education, 18(4): 26-32.

[10] Yunus, M. M., \& Salehi, H. (2012). The effectiveness of Facebook groups on teaching and improving writing: Students' perceptions. International Journal of Education and Information Technologies, 1(6): 87-96.

[11] Finlayson, H., \& Cook, D. (1998). The value of passive software in young children's collaborative work. IT for learning enhancement. Pp. 106-120.

[12] Brown, H. D. (2000). Principles of language learning and teaching.

[13] Pang, E. S., Muaka, A., Bernhardt, E. B., \& Kamil, M. L. (2003). Teaching reading. Brussels, Belgium: International Academy of Education.

[14] Wigfield, A., \& Guthrie, J. T. (1997). Relations of children's motivation for reading to the amount and breadth or their reading. Journal of educational psychology, 89(3): 420.

[15] Grabe, W., \& Kaplan, R. B. (2014). Theory and practice of writing: An applied linguistic perspective. Routledge.

[16] Maasum, T. N. R. T. M., \& Maarof, N. (2012). Empowering ESL readers with metacognitive reading strategies. Procedia-Social and Behavioral Sciences, 69: $1250-1258$

[17] Burt, M., Peyton, J. K., \& Adams, R. (2003). Reading and Adult English Language Learners: A Review of the Research. National Center for ESL Literacy Education (NCLE).

[18] Sulaiman, N., Muhammad, A. M., Ganapathy, N. N. D. F., Khairuddin, Z., \& Othman, S. (2017). Students' Perceptions on Using Different Listening Assessment Methods: Audio-Only and Video Media. English Language Teaching, 10(8): 93-99.

[19] Cheok, M. L., Wong, S. L., Ayub, A. F., \& Mahmud, R. (2017). Teachers' Perceptions of E-Learning in Malaysian Secondary Schools. Malaysian Online Journal of Educational Technology, 5(2): 20-33.

[20] Agudo, J. D. D. M. (Ed.). (2012). Teaching and learning English through bilingual education. Cambridge scholars publishing.

[21] Oliver, M., \& Trigwell, K. (2005). Can 'blended learning be redeemed? E-learning and Digital Media, 2(1): 17-26.

[22] Olisah Kingsley, S., \& Mohamed Ismail, Z. Web Based
E-learning System for Pre-school Kids.

[23] Christensen, R., \& Knezek, G. A. (2014). Measuring technology readiness and skills. In Handbook of research on educational communications and technology. Springer, New York, NY. pp. 829-840.

[24] Azizan, F. Z. (2010). Blended learning in higher education institution in Malaysia. In Proceedings of regional conference on knowledge integration in ICT. pp. 454-466.

[25] Zheng, S., Rosson, M. B., Shih, P. C., \& Carroll, J. M. (2015, February). Understanding student motivation, behaviors and perceptions in MOOCs. In Proceedings of the 18th ACM conference on computer supported cooperative work \& social computing. pp. 1882-1895.

[26] Mikropoulos, T. A., \& Natsis, A. (2011). Educational virtual environments: A ten-year review of empirical research (1999-2009). Computers \& Education, 56(3): 769-780.

[27] Ellaway, R., Dewhurst, D., \& Cumming, A. (2003). Managing and supporting medical education with a virtual learning environment: The Edinburgh Electronic Medical Curriculum. Medical Teacher, 25(4): 372-380.

[28] Dalgarno, B., \& Lee, M. J. (2010). What are the learning affordances of 3 - D virtual environment? British Journal of Educational Technology, 41(1): 10-32.

[29] Ebrahimi, S. S., \& Jiar, Y. K. (2018). The Use of Technology at Malaysian Public High Schools. Merit Research Journal of Education and Review, 6(3): 54-60.

[30] Berns, A., Gonzalez-Pardo, A., \& Camacho, D. (2013). Game-like language learning in 3-D virtual environments. Computers \& Education, 60(1): 210-220.

[31] Kamalludeen, R. M., Hassan, A., \& Nasaruddin, N. S. A. (2018). Student usage patterns of VLE-Frog. Journal of Personalized Learning, 2(1): 86-94.

[32] Loon, M., Evans, J., \& Kerridge, C. (2015). Reprint: Learning with a strategic management simulation game: A case study. The International Journal of Management Education, 13(3): 371-380.

[33] Hiong, S. N., \& Umbit, A. F. (2015). A pilot study on factors affecting the use of frog virtual learning environment. Jurnal Penyelidikan IPG KBL, 12: 1-17.

[34] Aypay, A., Celik, H. C., Aypay, A., \& Sever, M. (2012). Technology Acceptance in Education: A Study of Pre-Service Teachers in Turkey. Turkish Online Journal of Educational Technology-TOJET, 11(4): 264-272.

[35] Hew, T. S., \& Syed Abdul Kadir, S. L. (2016). Predicting instructional effectiveness of cloud-based virtual learning environment. Industrial Management \& Data Systems, 116(8): 1557-1584.

[36] Chua, C. L. (2006). Sample size estimation using Krejcie and Morgan and Cohen statistical power analysis: A comparison. Jurnal Penyelidikan IPBL, 7(1): 78-86.

[37] August, G. (2011). Spelling facilitates good ESL reading comprehension. Journal of Developmental Education, 35(1): 14.

[38] Yunus, M. M., Salehi, H. \& Nordin, N. (2012). ESL Pre-service Teachers' Perceptions on the Use of Paragraph Punch in Teaching Writing. English Language Teaching, 5(10): $138-147$. 